\title{
Population dynamics and the management of the Indo-Pacific king mackerel Scomberomorus guttatus from the upper Bay of Bengal off Bangladesh coast
}

\author{
H. Rashid*, M. G. Mustafa ${ }^{1}$ and S. Dewan \\ Department of Fisheries Management, Faculty of Fisheries, Bangladesh Agricultural \\ University, Mymensingh-2202, Bangladesh
}

\begin{abstract}
Growth and mortality parameters, exploitation rates, annual recruitment patterns and length-weight relationships were estimated using FiSAT program from monthly length-frequency and weight samples of Indo-Pacific king mackerel, Scomberomorus guttatus, captured mainly by drift gill nets from the upper Bay of Bengal off Bangladesh coast. The aim was to estimate growth parameters, mortality rates, exploitation rate and recruitment pattern of $S$. guttatus for sustainable management. The von Bertalanffy growth parameters asymptotic length $\mathrm{L}_{\infty}(\mathrm{cm})$ and growth constant $\mathrm{K}$ (per year) were 73.5 and 0.6 , respectively. The $\mathrm{L}_{\infty}$ and $\mathrm{Z} / \mathrm{K}$ estimates provided by Wetherall plot were 73.3 and $2.3 \mathrm{~cm}$. The annual rate of fishing mortality $(\mathrm{F}=0.806)$ was low compared to the relatively high natural mortality $(M=0.994)$. The exploitation rate $(E=0.45)$ shows that the species was not over-exploited in the region. About $77.1 \%$ of S. guttatus were recruited during May-July and $23.0 \%$ during September-October. The growth performance index $\left(\phi^{\prime}\right)$ was 3.5. The total length and body weight relationship was $\mathrm{W}=$ $0.0101 \mathrm{~L} 2.8622$ suggesting that the growth rate was negative allometric $(b<3)$. The growth parameters derived in the current study are comparable with previous estimates available for the same species. (Bangl. vet. 2010. Vol. 27, No. 2, 82 - 90)
\end{abstract}

\section{Introduction}

Scomberomorus guttatus known as Indo-Pacific king mackerel, is one of the commonly appearing Perciforms in the coastal waters of Bangladesh. It is also distributed from the Sea of Japan (Nakamura and Nakamura, 1982) to the Gulf of Thailand and the Persian Gulf (Collette and Russo, 1979). S. guttatus is a schoolforming tropical pelagic fish found mostly in clean coastal waters between 15 - to 200m depth: it prefers salinity between 25 and 39 ppt. Off the Bangladesh coast, it is captured mostly by using drift gill net. Locally, it is sold fresh or frozen as well as dry.

There are commercial fisheries, although large volumes are captured mainly by artisan fishermen. It is one of the principal species in the drift gill net fishery of Bangladesh, but the catch is not identified separately. However, a trawl survey (1984-86) conducted by Marine Fishery Survey unit of the Government of Bangladesh revealed that $S$. guttatus contributed $0.2 \%$ of total catch weight, which is the highest

1 WorldFish Center, Bangladesh and South Asia Office, House 22B, Road 7, Block F, Banani, Dhaka-1213, Bangladesh

*Corresponding author. E-mail: rashid.fish.bau@gmail.com 
(48.7\%) among scombrid fishes captured in the survey (Khan et al, 2003; Mustafa, 2003). To date, there is no information on the population parameters and lengthweight relationships of this species off the Bangladesh coast. However, there are reports on population parameters, fecundity, spawning and length-weight relationships of S. guttatus from the Gulf of Mannar and Palk Bay of India (Devaraj, 1981; Devaraj, 1987), from Rameswaram Island between India and Sri Lanka (Collette and Nauen, 1983) and from the western Indonesian coast (Pauly et al., 1996).

In the coastal waters of Bangladesh, the fishing pressure is increasing due to increase in the number of artisan fishing crafts. On the other hand, information on fishing pressure and stock position of important commercial fishes are limited. The objective of the present study was to estimate the population parameters and exploitation of $S$. guttatus, captured mainly by drift gill nets, to assess the stock status and sustainable management of the species in the upper Bay of Bengal near Cox's Bazar coast of Bangladesh.

\section{Materials and Methods}

Study area and sample collection

Fish samples were collected monthly from the commercial catches of fishermen, operating mainly drift gill nets, from November 1999 to October 2000. The sampling site was situated at Cox's Bazar $\left(21.26^{\circ} \mathrm{N}, 91.59^{\circ} \mathrm{E}\right)$, southeast Bangladesh, in the Bay of Bengal. Total length (Snout to caudal fin tip) and weight data were measured to the nearest $\mathrm{cm}$ and g, respectively, for a total of 2366 specimens of S. guttatus. Identification of S. guttatus from other species of same genus was done according to Collette and Nauen (1983).

\section{Estimation of population parameters}

For the estimation of population parameters, all the length-frequency data were pooled month-wise and grouped into length classes by $1 \mathrm{~cm}$ intervals. Data analysis were based on Electronic Length Frequency Analysis (ELEFAN I and II) computer program incorporated in FAO-ICLARM Stock Assessment Tool (Gayanilo et al., 1994). Asymptotic length $\left(\mathrm{L}_{\infty}\right)$ and growth constant $(\mathrm{K})$ values were estimated by ELEFAN I (Pauly and David, 1981; Saeger and Gayanilo, 1986). Fish growth is conventionally described in fisheries works by the Von Bertalanffy growth equation and in the notation of Beverton and Holt (1956) which is expressed as :

$$
L_{t}=L_{\infty}\left(1-e^{-k\left(t-t_{0}\right)}\right)
$$

Where Lt is the length at age t; L is the asymptotic length; e is the base of Napierian logarithm; $\mathrm{K}$ is the growth co-efficient and $t_{0}$ is the theoretical age at 0 lengths.

Additional estimate of $\mathrm{L}_{\infty}$ and total mortality/growth constant $(\mathrm{Z} / \mathrm{K})$ were obtained through the Powell-Wetherall Plot (Wetherall, 1986 as modified by Pauly, 1986): 


$$
L_{\text {mean }}-L^{\prime}=a+b L^{\prime}
$$

Where

$$
\mathrm{L}_{\text {mean }}=\frac{\mathrm{L}_{\infty}+\mathrm{L}^{\prime}}{1+(\mathrm{Z} / \mathrm{K})} \ldots
$$

from which

$$
L_{\infty}=-\mathrm{a} / \mathrm{b} \text { and } \mathrm{Z} / \mathrm{K}=(1+b) /-b
$$

Where $\mathrm{L}$ is defined as the mean length, computed from $\mathrm{L}^{\prime}$ upward, in a given length-frequency sample while $L^{\prime}$ is the limit of the first length class used in computing a value of $\mathrm{L}$.

The growth performance of $S$. guttatus population in terms of length-growth was based on the $\phi^{\prime}$ index of Pauly and Munro (1984) :

$$
\phi^{\prime}=\log _{10} K+2 \log _{10} L_{\infty}
$$

Where von Bertalanffy growth parameters, $\mathrm{K}$ and $\mathrm{L}_{\infty}$, were used.

Estimates of mortality were derived from the linearised length-converted catch curve produced by the ELEFAN II routine (Pauly, 1983; Saeger and Gayanilo, 1986). The ELEFAN II estimates the $Z$ from catch curve based on the equation:

$$
Z=\frac{K\left(L_{\infty}-L_{\text {mean }}\right)}{L_{\text {mean }}-L^{\prime}}
$$

Where, $\mathrm{L}_{\text {mean }}$ is the mean length of fish of length $\mathrm{L}$ ' and longer, while $\mathrm{L}$ ' is "some length for which all fish of that length and longer are under full exploitation." L' is the lower limit of the corresponding length interval (Beverton and Holt, 1956). (1980):

Natural mortality (M) was derived through the empirical equation of Pauly

$$
\log 10 M=0.0066-0.279 \log 10 L_{\infty}+0.6543 \log 10+0.463 \log 10 T
$$

Where $\mathrm{L}_{\infty}$ is expressed in $\mathrm{cm}, \mathrm{T}\left({ }^{\circ} \mathrm{C}\right)$ is the mean annual habitat temperature, taken as $28^{\circ} \mathrm{C}$. The estimate of fishing mortality $(\mathrm{F})$ was taken by subtraction of $\mathrm{M}$ from $Z$ (total mortality). An additional estimate of $Z$ was obtained by ELEFAN II (Jones and van Zalinge, 1981). The exploitation rate (E) was estimated from Gulland's (1971) equation $E=F / Z=F /(F+M)$.

Length-weight relationships

Total length in centimetres and total weight (calculated weight) in grams were used for estimating length-weight relationships of $S$. guttatus. The relationship 
between length and weight was described by the formula: $W=a . L^{b}$, where ' $a$ ' indicates the intercept and ' $b$ ' indicates slope of the regression line.

\section{Results and Discussion}

Growth parameters

Growth parameters of von Bertalanffy growth formula were estimated as $\mathrm{L}_{\infty}=$ $73.5 \mathrm{~cm}$ and $\mathrm{K}=0.6$ per year (Fig. 1). For these estimates through FiSAT the response surface ("explained sum of peaks" divided by the "available sum of peaks") was 0.150 , which generally ranges between 0 and 1 . The $t_{0}$ value was set to be 0 .

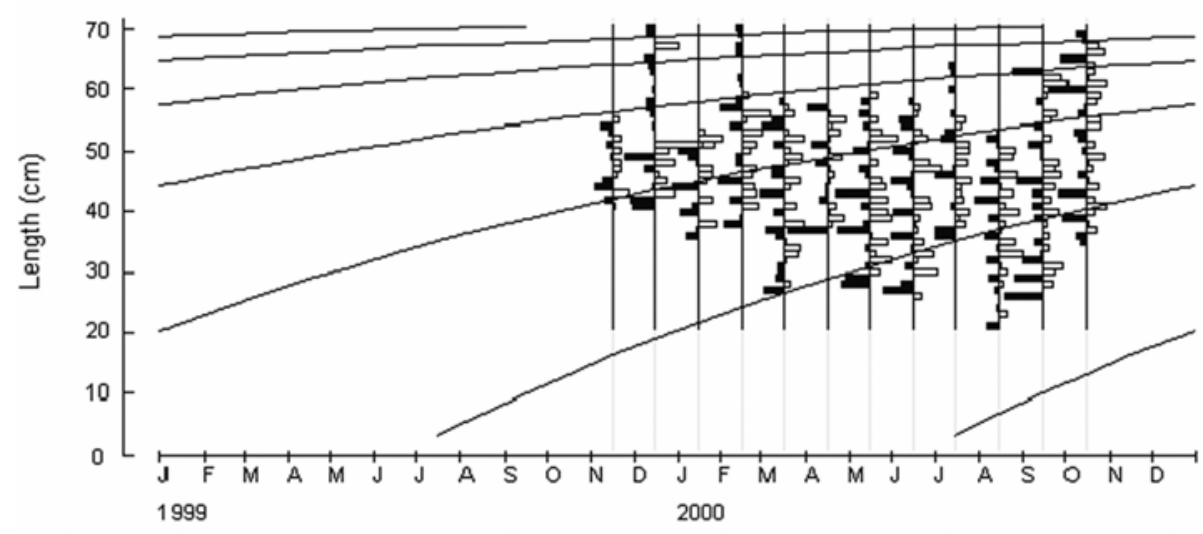

Fig. 1. Growth curve superimposed over restructured length-frequency data of S. guttatus

From the coast of South and south-west India, Devaraj (1981) reported $\mathrm{L}_{\infty}$ and $\mathrm{K}$ values of 127.8 and 0.2 , respectively, for S. guttatus (Table 1). In the present study the peak spawning took place during June-July (Fig. 1). Based on gonad index and ova diameter, Devaraj (1987) reported an extended spawning period from January to August, with a peak in April-May off the south coast of India. Collette and Nauen (1983) also reported spawning of S. guttatus from April to July around Rameswaram Island between India and Sri Lanka. The above reports on the spawning season (from April to July) are in agreement with our finding of peak recruitment (May-July). The $\mathrm{L}_{\infty}$ value reported by Devaraj (1981) is much higher than the value in our study, whereas the $\mathrm{K}$ value is much lower.

\section{Additional estimation of asymptotic length (Lo) total mortality/growth constant (Z/K)}

The modified Wetherall (1986) plot analysis incorporated in the FiSAT (Wetherall, 1986) yielded the regression line of $Y=22.12+(-0.302)^{*} \times$ and $r=0.981$. The corresponding estimates of $\mathrm{L}_{\infty}$ and $\mathrm{Z} / \mathrm{K}$ for $S$. guttatus are $73.30 \mathrm{~cm}$ and 2.313 , respectively (Fig. 2). This additional estimate of $\mathrm{L}_{\infty}$ is similar to previous $\mathrm{L}_{\infty}$ estimate through the von Bertalanffy growth formula. The estimation of $\mathrm{L}_{\infty}$ and $\mathrm{K}$ added a new observation of Pauly and Munro's (1984) Phi-prime index ( $\left.\phi^{\prime}\right)$ for S. guttatus was 3.5. In 
a study from the south coast of India, Devaraj (1981) reported $\phi^{\prime}$ value of 3.5 for $S$. guttatus, which is very close to the finding of the present study.

Table 1. Growth and mortality parameters of S. guttatus as compared between current study and previous studies

\begin{tabular}{l|c|c|c|c|c|c|c|c|c}
\hline \multirow{2}{*}{$\mathrm{L}_{\infty}$} & $\mathrm{K}$ & \multicolumn{3}{|c|}{$\begin{array}{c}\text { Mortality rate } \\
\text { (annual) }\end{array}$} & $\mathrm{E}$ & $\mathrm{b}$ & Study area & $\begin{array}{c}\text { Study } \\
\text { period }\end{array}$ & Source \\
\cline { 3 - 5 } & & $\mathrm{M}$ & $\mathrm{F}$ & $\mathrm{Z}$ & & & & & \\
\hline 73.5 & 0.6 & 1.0 & 0.8 & 1.8 & 0.5 & 2.9 & Bay of Bengal & $1999-2000$ & Current study \\
127.8 & 0.2 & - & - & - & - & 2.9 & $\begin{array}{c}\text { Gulf of Mannar } \\
\text { and Palk Bay }\end{array}$ & $1967-1969$ & Devaraj, 1981 \\
\hline
\end{tabular}

$\mathrm{L}_{\infty}$, asymptotic length ( $\mathrm{cm}$ ); $\mathrm{K}$, growth constant (per year); $\mathrm{M}$, natural mortality; $\mathrm{F}$, fishing mortality; $\mathrm{Z}$, total mortality; E, exploitation rate; $\mathrm{b}$, allometric coefficient

POWELL - WETHERALL PLOT

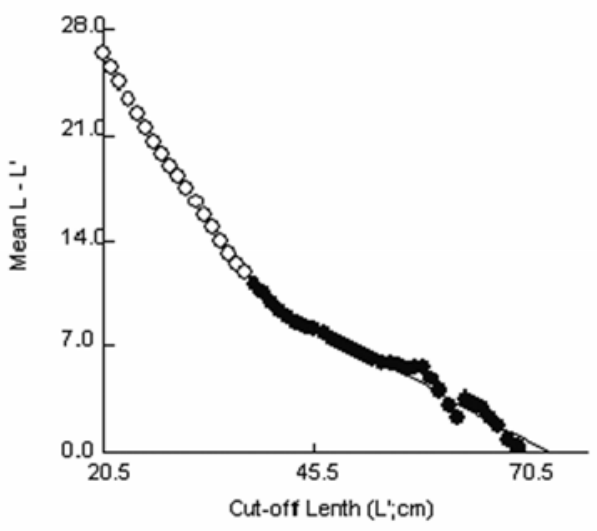

Fig. 2. Powell-Wetherall plot of $S$. guttatus $(\mathrm{L}=73.3 \mathrm{~cm}$ and $\mathrm{Z} / \mathrm{K}=2.313)$

\section{Mortality and exploitation rate}

The three different mortality rates $\mathrm{M}, \mathrm{F}$ and $\mathrm{Z}$ are summarized in Table 1. Figure 3 presents the catch curve utilized in the estimation of $Z$. The darkened circles in the figure represent length groups that are fully recruited into the fishery and the points used in calculation of $\mathrm{Z}$ via least squares linear regression. The correlation co-efficient for the regression was 0.851851 for $S$. guttatus. In the current study, the fishing mortality $(\mathrm{F})$ is lower than natural mortality $(\mathrm{M})$. The exploitation rate $(\mathrm{E})$ estimated from Gulland's (1971) equation, $E=F / F+M$. Thus from this range of values of $F$ and $\mathrm{Z}$ it can be shown that the rate of exploitation is 0.45 . It appears that the stock of $S$. guttatus is not over-exploited. This assumption is based on Gulland (1971), who stated that suitable yield is optimized when $F=M$, and when $E>0.5$ the stock is generally supposed to be over fished. 
In agreement with the low F value, our study revealed that $S$. guttatus obtained from drift gill net catches of upper Bay of Bengal were not over-exploited. However, we did not find any report on the mortality parameters of this species from the Bay of Bengal or from any other locality.

\section{Recruitment pattern}

Recruitment pattern (Fig. 4) from length-frequency data is correlated with the length of spawning season and growth co-efficient (K). Recruitment pattern suggested two uneven seasonal pulses in May-July (peak recruitment) and OctoberNovember (lean recruitment). It appears from original pattern of recruitment with superimposed normal distribution that this species is recruited $71.7 \%$ during peak recruitment and $28.3 \%$ during lean recruitment.

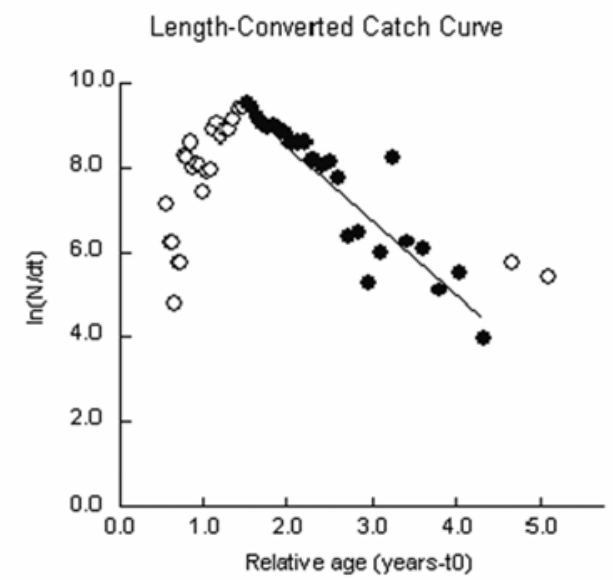

Fig. 3. Length-converted catch curve of $S$. guttatus (darkened circles represents length groups that are fully recruited into the fishery and used in the analysis)

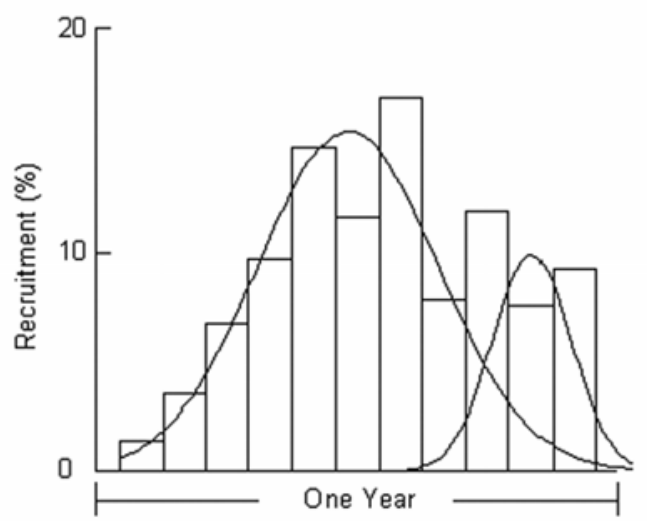

Fig. 4. Recruitment pattern of S. guttatus

Figure 5 shows the yield-per-recruit isopleths diagram of the various length at entry for S. guttatus into the fishery based on different values of $\mathrm{E}$ and a constant value of $M=0.994$. The discontinued curves indicate the range which produced the maximum yield-per-recruit. The maximum value of relative yield-per-recruit at the meeting point of the eumetric yield curve with the maximum sustainable yield (MSY) curve at $\mathrm{E}=0.5$ and $\mathrm{Lc}=40.3 \mathrm{~cm}$ was so-called potential yield-per-recruit. Hence, the value of $\mathrm{Lc}=40.3 \mathrm{~cm}$ should be considered as the size of exploitation at which the biomass (standing stock) attains its maximum size.

\section{Length-weight relationships}

Total length and body weight ranged from 25 to $70 \mathrm{~cm}$ and 120 to $2050 \mathrm{~g}$, respectively. From the regression analysis of the length and weight data, the 
relationship was found to be $\mathrm{W}=0.0101 \mathrm{LL}^{2.8622}$ (Fig. 6). The value of the allometric coefficient $(b=2.8622)$ in this study was less than 3 , indicating that the fishes increased in weight a power lesser than the cube of length i.e., their growth was negative allometric (Table 1 ).

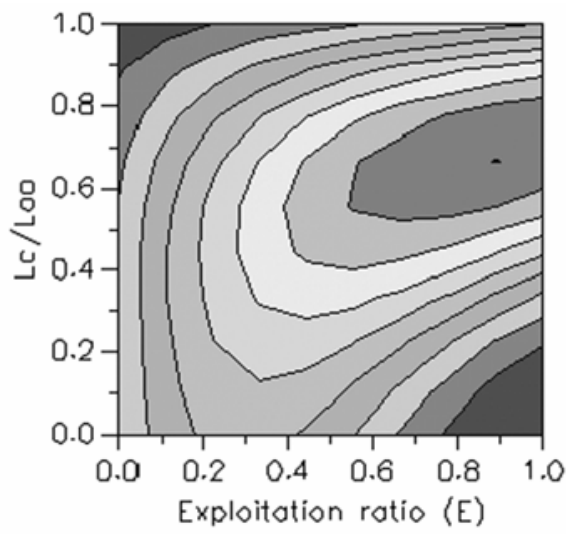

Fig. 5. Yield per recruit isopleths diagram of $S$. guttatus $(\mathrm{M} / \mathrm{K}=1.656)$

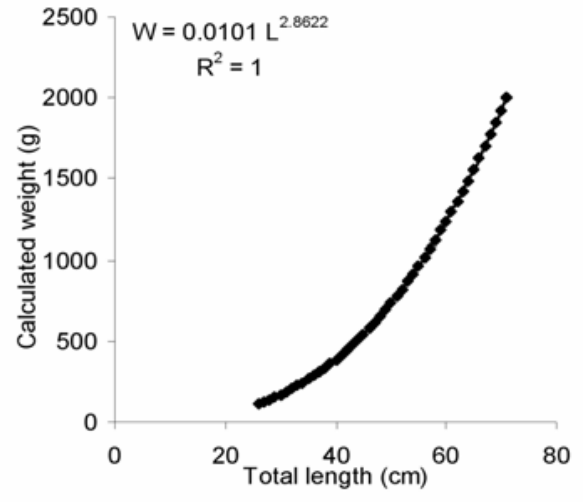

Fig. 6. Relationships between total length and body weight (calculated) of S. guttatus from the upper Bay of Bengal off Bangladesh coast

Devaraj (1981) also reported a negative allometric growth rate of S. guttatus $(b=2.86)$ from South and south-west India, which is in agreement with our study. On the other hand, Pauly et al. (1996) report on $b$ value $(b=3.002)$ for $S$. guttatus from western Indonesian coast was almost isometric.

\section{Conclusions}

This is the first ever study on the population parameter and length-weight relationships of S. guttatus sampled from the commercial catches of drift gill nets in the upper Bay of Bengal off Bangladesh coast. The growth and mortality parameters provide an important guideline for fisheries management of this species. However, detailed studies on maturity, reproduction, yield-per-recruit and biomass-per-recruit are needed for proper management of fishery stock of this commercially important fish species.

\section{Acknowledgements}

The authors are grateful to the fishermen and fish traders of Bangladesh Fisheries Development Corporation fish landing center at Cox's Bazar, Bangladesh, for providing assistance and help during sampling and data collection of this species. 


\section{References}

Beverton RJH, Holt SJ 1956: A review of method for estimating mortality rates in fish population, with special references to sources of bias in catch sampling. Rapports et Proces-verbaux des Réunions. Conseil International pour Éxploration de la Mer 140 67-83.

Collette BB, Russo JL 1979: An introduction to the Spanish mackerels, genus Scomberomorus. In: Proceedings of Colloquium on the Spanish and King Mackerel Resources of the Gulf of Mexico. Eds: Nakamura EL; Bullis HR Jr., Gulf States Marine Fisheries Commission Publication 4 3-16.

Collette BB, Nauen CE 1983: FAO species catalogue. Vol. 2. Scombrids of the world. An annotated and illustrated catalogue of tunas, mackerels, bonitos and related species known to date. FAO Fisheries Synopsis $\mathbf{1 2 5} 137$

Devaraj M 1981: Age and growth of three species of seerfishes Scomberomorus commerson, S. guttatus and S. lineolatus. Indian Journal Fisheries 28104 -127.

Devaraj M 1987: Maturity, spawning and fecundity of the spotted seer, Scomberomorus guttatus, in the Gulf of Mannar and Palk Bay. Indian Journal of Fisheries 34 48-77.

Gayanilo FC Jr., Sparre P, Pauly D 1994: The FAO-ICLARM stock assessment tools (FiSAT) user's guide. FAO Computerized Information Series (Fisheries) 6186.

Gulland JA 1971: The fish resources of the Oceans, West by fleet, Survey, Fishing News (books), for FAO 255.

Jones R, van Zalinge NP 1981: Estimation of mortality rate and population size for shrimp in Kuwait waters. Kuwait Bulletin of Marine Science 2 273-288.

Khan MAA, Sad NU, Chowdhury ZA 2003: Status of the demersal fishery resources of Bangladesh. In: Assessment, Management and Future Direction of Coastal Fisheries in Asian Countries. Eds: Silvestre G, Garces L, Stobutzki I, Ahmed M, ValmonteSantos RA, Luna C, Lachica-Aliño L, Munro P, Christensen V, Pauly D, WorldFish Center Conference Proceeding 67 63-82.

Mustafa MG 2003: Trophic model of the coastal ecosystem in the waters of Bangladesh Bay of Bengal. In: Assessment, Management and Future Direction of Coastal Fisheries in Asian Countries. Eds: Silvestre G, Garces L, Stobutzki I, Ahmed M, Valmonte-Santos RA, Luna C, Lachica-Aliño L, Munro P, Christensen V, Pauly D, WorldFish Center Conference Proceeding 67 263-280.

Nakamura I, Nakamura R 1982: New records of two species of Scomberomorus from Japan. Japanese Journal of Ichthyology 28 445-449.

Pauly D 1980: On the interrelationships between natural mortality, growth parameters, and mean environmental temperature in 175 fish stocks. Journal du Conseil International pour Exploration de la Mer 39 175-192.

Pauly D 1983: Some simple methods for the assessment of tropical fish stocks. FAO Fisheries Technical Paper 23552.

Pauly D 1986: On improving operation and use of the ELEFAN programs. Part II. Improving the estimation of $\mathrm{L}_{\infty}$. Fishbyte 4 18-20. 
Pauly D, Cabanban A, Torres Jr. FSB 1996: Fishery biology of 40 trawl-caught teleosts of western Indonesia. In: Baseline studies of biodiversity: the fish resource of western Indonesia. Eds: Pauly D, Martosubroto P, ICLARM Studies and Reviews 23 135-216.

Pauly D, David N 1981: ELEFAN I: a basic program for the objective extraction of growth parameters from length-frequencies data. Meeresforsch 28 205-211.

Pauly D, Munro JL 1984: Once more on growth comparisons in fish and invertebrates. Fishbyte 21.

Saeger J, Gayanilo FC Jr. 1986: A revised and graphic orientated version of the ELEFAN 0, I and II programs for use on HP 86/87 microcomputers. Technical Report Department of the Marine Fisheries 8 1-233.

Wetherall JA 1986: A new method for estimating growth and mortality parameters from length-frequency data. Fishbyte 4 12-14. 